\title{
Construction and calibration of a rapidly responding pH mini-electrode: application to intertidal sediments*
}

\author{
S. A. de Jong, P. A. G. Hofman, A. J. J. Sandee \\ Delta Institute for Hydrobiological Research, Vierstraat 28, 4401 EA Yerseke, The Netherlands
}

\begin{abstract}
The construction and calibration is described of a new type of $\mathrm{pH}$ glass electrode with a measuring bulb of $1.0 \mathrm{~mm}$ in diameter The lower one-fourth zone of the bulb, a 15 to $70 \mu \mathrm{m}$ thick membrane of $\mathrm{pH}$ glass, contributed at least $70 \%$ to the final reading, hence allowing a spatial resolution down to $100 \mathrm{~mm}$. The $90 \%$ response time depended on temperature and varied from $20 \mathrm{~s}$ at $0^{\circ} \mathrm{C}$ to $5 \mathrm{~s}$ at $36^{\circ} \mathrm{C}$ in buffer solutions and from 5 to $15 \mathrm{~s}$ in sediment at $18^{\circ} \mathrm{C}$. A maximal deviation of $4 \%$ resulted from the use of standard buffers for calibration instead of saline buffers. Over the temperature and $\mathrm{pH}$ range tested $\left(0\right.$ to $36^{\circ} \mathrm{C}$ and $\mathrm{pH} 7$ to 10$)$ the mini-electrode showed a linear response. Responses varied from 91 to $98 \%$ of those calculated from the Nernstian equation. In melting ice $75 \%$ of the Nernstian response was still found. The sturdy bulb of the mini-electrode allows its use in muddy as well as sandy sediments. The short response time and high spatial resolution permit the measurement of vertical $\mathrm{pH}$ gradients at microscale, parallel to such gradients in oxygen, measured with oxygen microelectrodes. An example is given of a combined measurement of the photosynthetic activity of benthic microalgae, $\mathrm{pH}$, and oxygen in an estuarine sediment.
\end{abstract}

\section{INTRODUCTION}

During the last decade, microelectrodes have been developed for use in marine and estuarine sediments. The use of these electrodes has increased our insight into the microbiological and geochemical processes in a variety of biotopes. Ecological processes in the oxic layer of intertidal flats cannot be understood without knowledge of the fluctuations of oxygen and $\mathrm{pH}$. Recent studies have shown large daily fluctuations in oxygen and $\mathrm{pH}$ due to the activity of bacteria and microalgae (Revsbech et al. 1983, Revsbech \& Ward 1984, Jørgensen et al. 1983, Rasmussen et al. 1983). Ultrafine $\mathrm{pH}$ microelectrodes of glass developed for intracellular measurements were described by Carter \& Pucacco (1978) and Thomas (1978). The latter description was used by Revsbech and coworkers for their $\mathrm{pH}$ microelectrodes. The electrical resistance of scaleddown $\mathrm{pH}$ microelectrodes increased the time needed for stabilization from 15 to $180 \mathrm{~s}$ (Carter \& Pucacco, 1978). This implies that a suitable compromise has to be found between tip size and adequate response time,

\footnotetext{
- Communication No. 399 of the Delta Institute
}

depending on the aim of the research. Application in estuarine and marine sediments requires rapidly responding electrodes as $\mathrm{pH}$ may change during the measuring procedure. The construction of a rapidly responding, sturdy $\mathrm{pH}$ glass mini-electrode is described here as well as the method used for calibration. The properties of this mini-electrode are discussed with respect to spatial resolution and response time. An example of in situ application in an intertidal flat is presented.

\section{MATERIAL AND METHODS}

Construction. The tip of the mini-electrode is made of Corning $0150 \mathrm{pH}$ glass. This glass is composed of $\mathrm{SiO}_{2}(72 \%), \mathrm{Na}_{2} \mathrm{O}(22 \%)$ and $\mathrm{CaO}(6 \%)$, and exhibits a Nernstian response to $\mathrm{H}^{+}$ions up to $\mathrm{pH} 11$ to 12 (Lakshminarayanaiah 1976). A tube of Corning 0150 glass, $2.5 \mathrm{~cm}$ in length and $2 \mathrm{~mm}$ wide, is pulled to a fine capillary with a micropipette puller to a final outer diameter of 0.2 to $0.5 \mathrm{~mm}$; the thickness of the wall is then ca $0.1 \mathrm{~mm}$. The open end of the capillary is closed by heating with a circular microforge heating element 


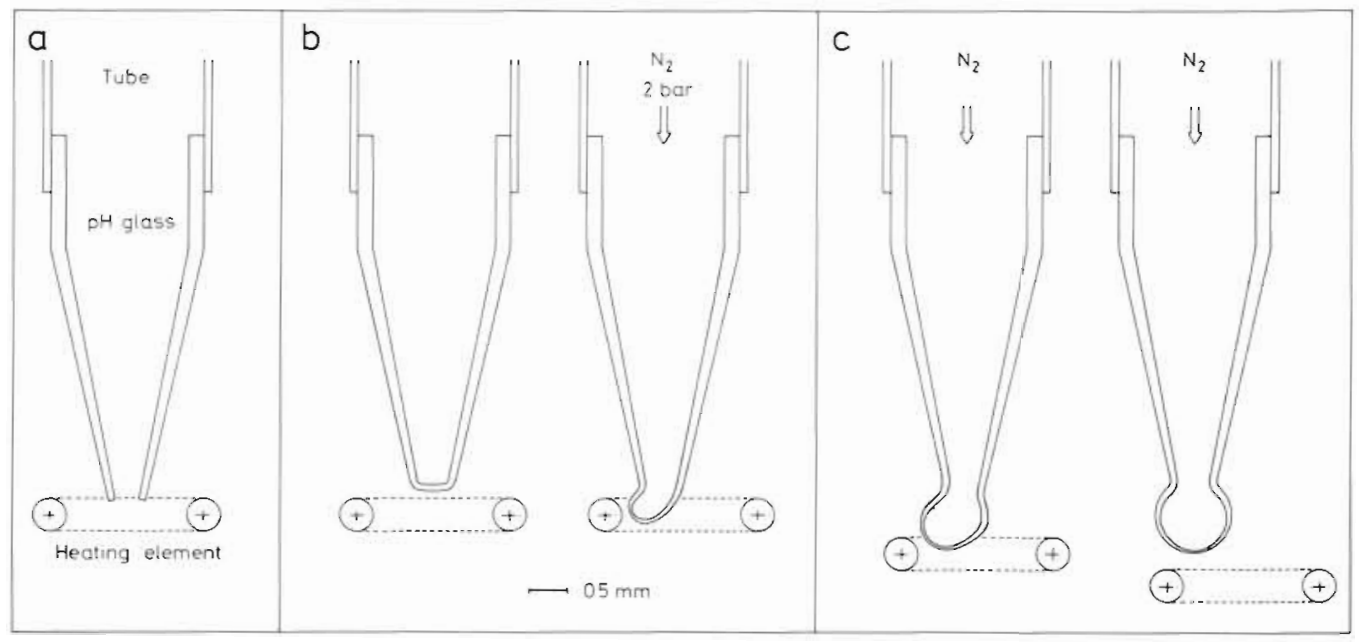

Fig. 1. Construction of the $\mathrm{pH}$ bulb. $(\mathrm{a}, \mathrm{b})$ Pulling of glass capillary with a circular microforge heating element. $(\mathrm{b}, \mathrm{c})$ Blowing of the bulb with $\mathrm{N}_{2}$ at pressure 2 atm. The heating element is first moved towards the bulb to make one side thinner. Afterwards, the element is moved down and to one side lo move the partially thinned glass to the lower part of the bulb

(Fig. 1a). The transformation of the closed end into a rounded bulb results from the interaction of the heating at the tip and the blowing of $\mathrm{N}_{2}$-gas into the open end of the tube (Fig. 1b). The heating element is first moved towards one side to create a thinner wall. This side is moved downwards by moving the heating element relative to the bulb (Fig. 1c). With experience, perfect spheres can be formed with bulbs varying in diameter 0.1 to $1.0 \mathrm{~mm}$; we preferred 0.5 to $1.0 \mathrm{~mm}$ bulbs for measurements in sediments as will be discussed later. The glass thickness of the side and lower parts depends on the distance between the heating element and the tip. For a $1 \mathrm{~mm}$ bulb it decreased from $100 \mu \mathrm{m}$ in the upper part to $15 \mu \mathrm{m}$ in the lower part. The electrode is glued into a pasteur pipette (WU, Mainz, FRG) with a 2-component glue based on epoxy resins (Uhu/Fismar, FRG). The connection must be watertight to ensure correct measurements. The total length of the protruding $\mathrm{pH}$ tip varies from 5 to $15 \mathrm{~mm}$.

The electrode is filled under vacuum to prevent formation of micro gas bubbles. The internal electrolyte is a mixture of $0.1 \mathrm{M}$ sodium citrate and $0.1 \mathrm{M}$ sodium chloride. To prevent microbial growth inside the electrode, silver nitrate is added to a final concentration of $1 \%$. On top of the internal solution a drop of paraffin oil is added to close the electrode and prevent evaporation.

A $24 \mathrm{~h}$ period of stabilization is needed for the equilibration of the $\mathrm{pH}$ glass and its internal solution. The electrodes are stored at $4{ }^{\circ} \mathrm{C}$ in a tube containing the internal electrolyte solution. The lifetime is then about 6 mo. For longer storage the electrodes should be left unfilled. Between daily measurements the $\mathrm{pH}$ minielectrode is kept in seawater of ambient temperature and salinity. In this way large $\mathrm{pH}$ changes are pre- vented, prolonging its lifetime. Decline of the potential difference per $\mathrm{pH}$-unit or sudden shifts in potential readings indicate malfunctioning.

\section{RESULTS AND DISCUSSION}

\section{Calibration}

The response of each newly-made $\mathrm{pH}$ mini-electrode is checked for its response time at a pH interval of 7 to 10 before use. This interval includes all $\mathrm{pH}$ values encountered in measurements in sediments of the Oosterschelde estuary (The Netherlands). Earlier tests showed responses close to theoretical values between pH 4 to 11 .

The buffer solutions used are commercially available (Merck). Saline buffer solutions were made by adding sodium chloride (Merck p.a.) to obtain a final salinity of $30 \%$.

The experimental set-up consisted of a sturdy metal rack with a motor-driven micromanipulator (Ull/Assler, FRG) holding the $\mathrm{pH}$ mini-electrode. The mini-electrode was linked to a $\mathrm{pH} / \mathrm{mV}$ meter (PHM 82 Radiometer Copenhagen, Denmark) by a silver wire connecting the internal solution with a shielded cable. The high electrical resistance of the mini-electrode, $10^{10}$ to $10^{12} \Omega$, makes it very sensitive to interferences of static electricity or short-circuiting by moisture. Therefore proper insulation and shielded cables are required. A single junction reference electrode with ceramic grit (Radiometer Copenhagen, Denmark) was connected to the $\mathrm{pH} / \mathrm{mV}$ meter, which was stored in a waterproof housing.

We tested the $\mathrm{pH}$ mini-electrode in 4 standard buffer 
solutions over a temperature range of 0 to $36^{\circ} \mathrm{C}$. At each temperature the corresponding $\mathrm{pH}$ values were corrected according to the manufacturer's information or by additional calibration with a $\mathrm{pH}$ macro-electrode (GK 2421C, Radiometer Copenhagen, Denmark) coupled to a similar reference electrode as used for the mini-electrode. Linear regression analysis always showed high correlation coefficients between $\mathrm{pH}$ and potential difference, ranging from $r=0.999$ at $0.0^{\circ} \mathrm{C}$ to $r=1.000$ at $35.6^{\circ} \mathrm{C}, n=4$. The lowest sensitivity was found in melting ice. The theoretical relationship between slope and temperature is defined by the Nernst equation. This equation predicts sensitivities of 58.2 and $60.1 \mathrm{mV} \mathrm{pH}^{-1}$ at 20 and $30^{\circ} \mathrm{C}$, respectively (Fig. 2). Measured slopes were between 95 and $98 \%$ of

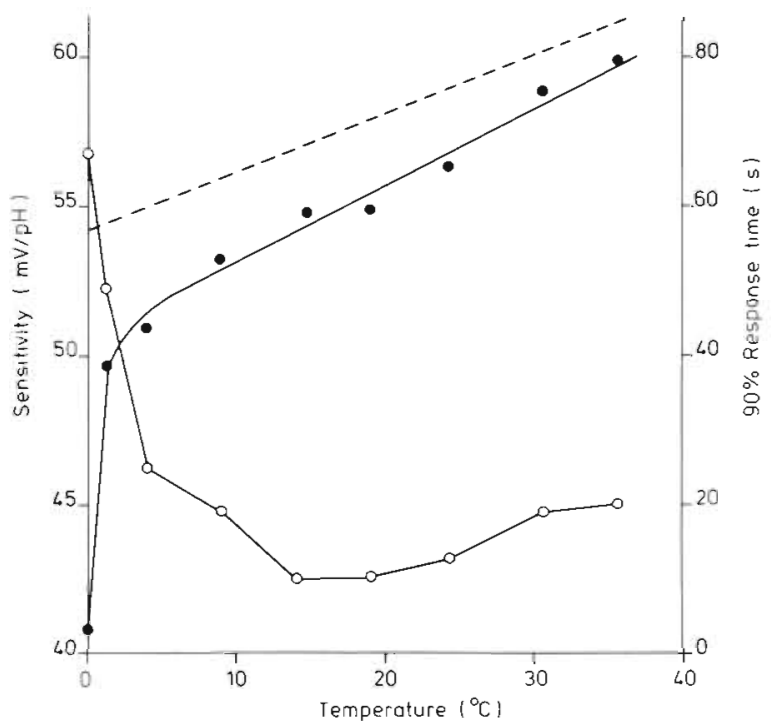

Fig. 2. Sensitivity $\left(\bullet ; \mathrm{mV} \mathrm{pH}^{-1}\right)$ and $90 \%$ response time $(0 ; \mathrm{s})$ measured at steps of $1 \mathrm{pH}$-unit in $\mathrm{S}=30$ buffer solutions with temperature ranging from 0 to $36^{\circ} \mathrm{C}$. Dashed line represents the sensitivity calculated according the Nernst equation, slope $=0.198$. A slope of $0.269(n=8, r=0.988)$ was calculated from the measured sensitivities (solid line) for the $\mathrm{pH}$ mini-electrode tested, excluding the 'melting ice' point

the Nernstian slopes over the range of 9 to $36^{\circ} \mathrm{C}$ decreasing to between 91 and $93 \%$ at 1 to $9^{\circ} \mathrm{C}$. In melting ice $75 \%$ of the Nemstian response was still found. The non-ideal response at temperatures lower than $2{ }^{\circ} \mathrm{C}$ is probably due to retarded diffusion and the presence of ice in the solution. Field measurements in ice-covered sediments showed unreliable and unstable signals, indicating slow exchange over the $\mathrm{pH}$ glass membrane.

The accuracy of $\mathrm{pH}$ measurements is subject to discussion. Differences in set-up or sets of electrodes introduce several sources of error. The main technical error results from the use of different junctions between
$\mathrm{pH}$ and reference electrode. Although the free diffusion liquid junction provides the best alternative, its application causes problems in sediment. We used a reference electrode with a permeable ceramic grit for calibration and in situ measurements. The deviation can be reduced to $0.01 \mathrm{pH}$-unit when the same pair of $\mathrm{pH}$ and reference electrode are used throughout a series of measurements (Whitfield et al. 1985).

A second source of errors arises from physical factors, such as temperature and salinity. In our tests we calculated the effect of temperature to be $0.27 \mathrm{mV} \mathrm{pH}{ }^{-1}{ }^{\circ} \mathrm{C}^{-1}$ between 1 and $36^{\circ} \mathrm{C}$, somewhat larger than that predicted from the Nernstian equation, $0.20 \mathrm{mV} \mathrm{pH}^{-1{ }^{\circ} \mathrm{C}^{-1}}$ (Fig. 2). The effect of salinity was a shift in the reading of the potential of the buffer solutions due to changed conductivity which decreased the original pH value. The phosphate-based $\mathrm{pH} 7$ buffer shifted from 7.0 to 6.62 , whereas the 3 borate-based buffers of $\mathrm{pH} 8,9$ and 10 each decreased $0.16 \mathrm{pH}$-unit. However, only slight changes in sensitivity ( 1 to $4 \%$ ), compared to standard fresh buffer solutions, were found. In other studies salt shifts varied from 0.01 to $0.09 \mathrm{pH}$-unit (Schwabe 1974 , Butler et al. 1985. Whitfield et al. 1985, Millero 1986). Millero stated that for $\mathrm{pH}$ determination over a salinity range of 5 to 40 , any set of buffers at a fixed salinity can be used, introducing a shift of $0.01 \mathrm{pH}$-unit at most. The transition of $S=0$ to $S=5$, however, may cause larger errors, up to $0.09 \mathrm{pH}$-unit.

\section{$90 \%$ response time and drift}

The $90 \%$ response time is defined as the time needed to reach $90 \%$ of the stabilized value (Revsbech et al. 1983). These times were estimated from the recorder readings. An average was calculated from each series of 4 buffers. The most rapid responses were found between 15 and $25^{\circ} \mathrm{C}$ (Fig. 2). Over the range 9 to $36^{\circ} \mathrm{C}$, response times varied little, 10 to $20 \mathrm{~s}$. At temperatures lower than $2{ }^{\circ} \mathrm{C}$ the time needed for $90 \%$ stabilization was significantly longer, 49 to $67 \mathrm{~s}$, applying in this case to shifts of $1 \mathrm{pH}$-unit. On moving the $\mathrm{pH}$ mini-electrode to buffer solutions with similar $\mathrm{pH}$, stabilization was seen within a few seconds.

The $90 \%$ response time gives only a rough indication of the sensitivity. Even a very sensitive electrode exhibits response times of 5 to $50 \mathrm{~s}$ due to changes in temperature and hence diffusion velocities. We used a standard $90 \%$ response time of maximal $10 \mathrm{~s}$ at $20^{\circ} \mathrm{C}$ at a shift of $1 \mathrm{pH}$-unit as a testing norm; electrodes with slower response times were not used as their bulb walls were to thick to allow fast diffusion.

The electrode drift was very small, 1 to $12 \mathrm{mV} \mathrm{h}^{-1}$ at $20^{\circ} \mathrm{C}$, which corresponds to a maximal drift of 0.004 $\mathrm{pH}$-unit $\mathrm{min}^{-1}$. 


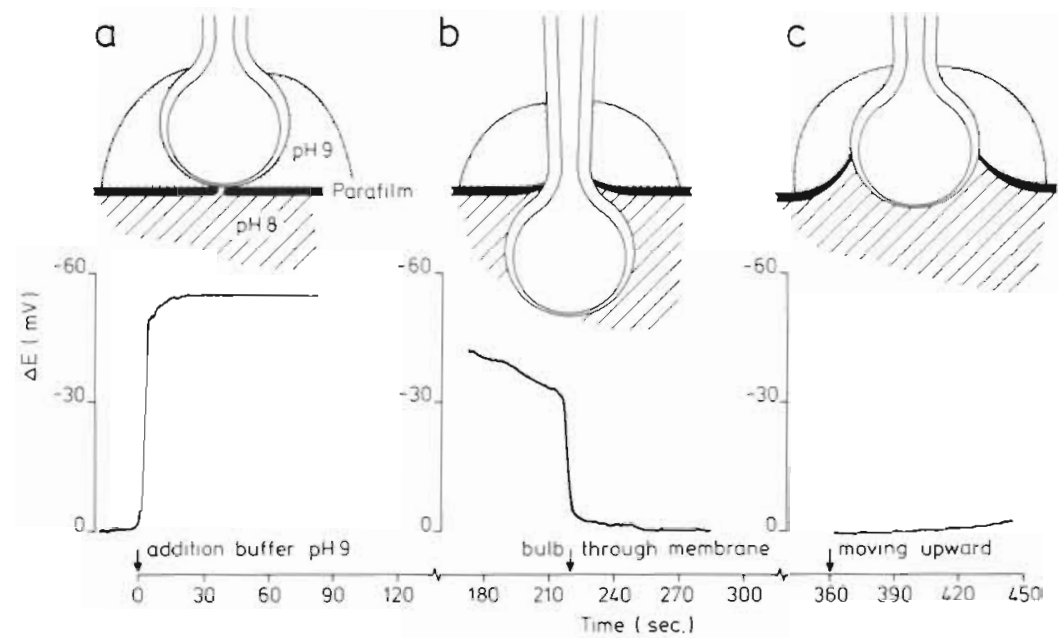

Fig. 3. Test procedure used to determinate the actual measuring zone of the bulb of a $\mathrm{pH}$ mini-electrode. The bulb was separated from 2 different buffers by a thin parafilm with a hole of $50 \mu \mathrm{m}$. (a) At time $=0 \mathrm{~s}$ a drop of buffer solution ( $\mathrm{pH} 9.0$ ) was added to the upper side of the parafilm. (b) At time $=180$ $\mathrm{s}$ the bulb was pushed gradually through the parafilm membrane. After $220 \mathrm{~s}$ the whole bulb was situated below the parafilm membrane. (c) At time $=360 \mathrm{~s}$ the electrode was gently moved upwards. The situation illustrated was reached after $450 \mathrm{~s}$

\section{Spatial resolution}

A specific test was carried out to determine the actual measuring zone of the tip and thereby its spatial resolution. The method used allowed discrimination between slow-and rapid-responding areas of the bulb. We took a $1 \mathrm{~mm}$ bulb-sized electrode exhibiting maximal response time at $20^{\circ} \mathrm{C}$ in order to make a maximal estimation of the measuring error involved in measuring sub-millimeter intervals. The electrode was held with the tip touching a stretched parafilm membrane (Fig. 3a). This membrane separated 2 buffer solutions of $\mathrm{pH} 8.0$ and 9.0. A hole of approximately $50 \mu \mathrm{m}$ was made to provide contact between electrode and underlying solution. The liquid contact through the small connecting hole was sufficient to establish a stable recording signal. When a drop of pH 9 buffer was added the electrode signal showed a shift of $55 \mathrm{mV}$ within $10 \mathrm{~s}$. The electrode was then moved through the membrane while recording the signal continuously together with microscopic observation. A gradual decrease of the electrode signal was seen as the bulb moved downwards through the membrane (Fig. 3b). As soon as half of the bulb had passed the membrane, the membrane closed at the neck and the signal dropped almost instantly to the original pH 8.0 value. This means that the $\mathrm{pH}$ is measured by the bulb-formed tip of the mini-electrode. Moving the tip upwards gave further information about the actual measuring zone (Fig. 3c). A small drift of $2 \mathrm{mV}$ was measured when $3 / 4$ of the bulb had passed the membrane. Additional microscopic study of the bulb showed that the thickness of the glass membrane narrowed from 70 to $15 \mu \mathrm{m}$ in the lower $1 / 4$ part. Over the lowest 100 um zone the 15 to $25 \mu \mathrm{m}$ thick glass favoured exchange of $\mathrm{H}^{+}$ions in a $5: 2$ ratio relative to the adjacent $200 \mu \mathrm{m}$ zone above. This means that at least $70 \%$ of the response was obtained via the thinnest part of the bulb. It also implied a minimal spatial resolution of $100 \mu \mathrm{m}$ at $1 \mathrm{~mm}$ bulb-size.

\section{Application to intertidal sediments}

An in situ measurement in estuarine sediment was carried out with an oxygen microelectrode and a $\mathrm{pH}$ mini-electrode. The oxygen microelectrodes were constructed according to the description given by Revsbech (1983). Photosynthesis was measured in

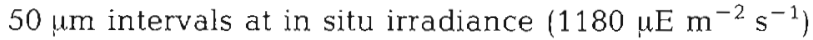
and temperature $\left(18.2^{\circ} \mathrm{C}\right)$, using the darkening technique described by Revsbech \& Jørgensen (1983). Calibration of the oxygen microelectrode was done in seawater of ambient temperature by Winkler titration direct after the measurement. Calibration of the $\mathrm{pH}$ mini-electrode took place directly after measuring in 3 buffers covering the $\mathrm{pH}$ range measured, 7 to 9 . The buffers were kept at ambient temperature without exposure to direct sunlight. A sediment sample was taken with a plexiglass corer of $20 \mathrm{~cm}$ length and $6 \mathrm{~cm}$ width from an emersed intertidal sandflat in the Oosterschelde estuary, southwestern Netherlands, on 11 June 1986. Oxygen and photosynthesis profiles were measured within $10 \mathrm{~min}$ after sampling under in situ conditions of irradiance and temperature at the sampling site $e_{i}$ this took 10 min for 2 profiles. The first measured profile of photosynthesis and oxygen is shown in Fig. 4. The pH profile was measured immediately after the photosynthesis measurements. Intervals of $0.1 \mathrm{~mm}$ were measured up to $1.5 \mathrm{~mm}$ depth, and $0.5 \mathrm{~mm}$ intervals to a depth of $5.0 \mathrm{~mm}$ (Fig. 4). The whole profile was completed in $8 \mathrm{~min}$.

The $90 \%$ response time was maximally $5 \mathrm{~s}$ when moving over $100 \mu \mathrm{m}$ intervals with a $\mathrm{pH}$ change of 0.05 to 0.50 . At greater depth intervals longer response 


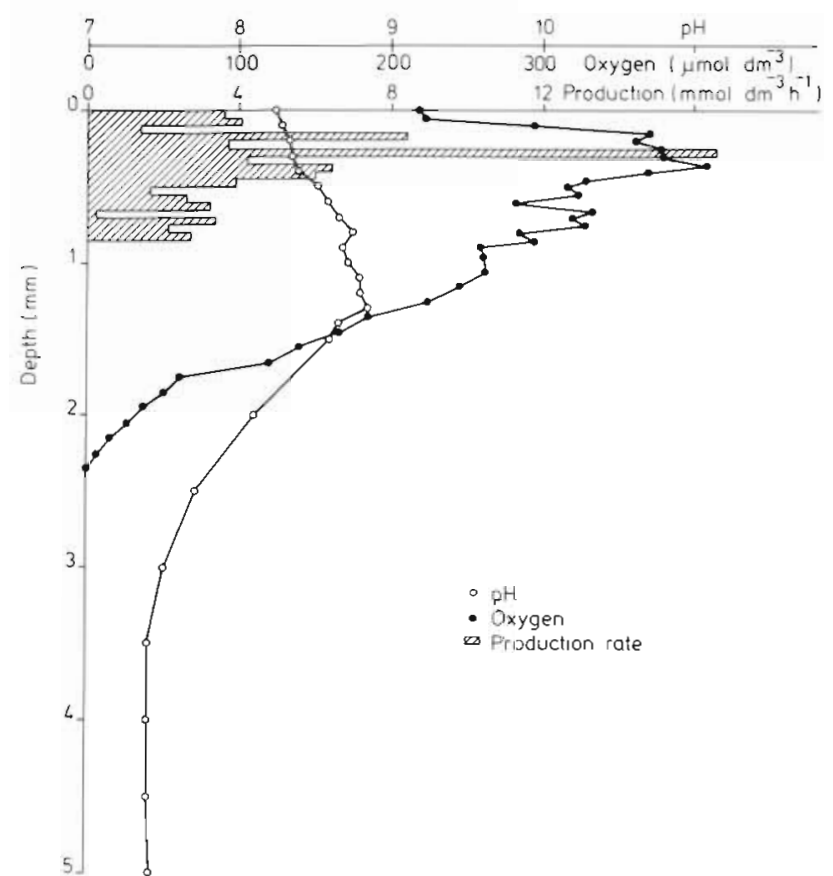

Fig. 4. Depth profiles of pH (o), oxygen $\left(\bullet \mu \mathrm{mol} \mathrm{dm}{ }^{-3}\right.$ interstitial water) and photosynthetic rate (bars; $\mathrm{mmol} \mathrm{dm}^{-3}$ wet sediment $\mathrm{h}^{-1}$ ) measured in a sandy emersed intertidal flat, 11 June 1986. Measurements took place at in situ conditions of irradiance $\left(1180 \mu \mathrm{E} \mathrm{m}^{-2} \mathrm{~s}^{-1}\right)$, temperature $\left(18.2^{\circ} \mathrm{C}\right)$, and salinity $(S:=34.8)$ immediately after sampling $(10: 50 \mathrm{~h})$. Calibration was done with 3 standard buffers $(7.0,8.0$ and 9.0$)$ with a calculated sensitivity of $54.2 \mathrm{mV} \mathrm{pH}^{-1}(n=3, r=1.000)$

times were recorded, 10 to $15 \mathrm{~s}$ at correspondingly higher $\mathrm{pH}$ changes. The in situ response times, corrected to $1 \mathrm{pH}$-unit change, were similar to those measured in buffer solutions at $20^{\circ} \mathrm{C}$.

As can be seen from the sediment profile, $\mathrm{pH}$ changes are less extreme than those in the oxygen profile. A maximum $\mathrm{pH}$ of 8.9 was reached at $1.3 \mathrm{~mm}$ depth, while at the surface a $\mathrm{pH}$ value of 8.2 was recorded. Below the oxic zone the $\mathrm{pH}$ stabilized at 7.5 . Photosynthetic activity of benthic diatoms, which dominated in these sediments, was measured to a depth of $0.85 \mathrm{~mm}$ with maximal values at $0.3 \mathrm{~mm}$.
An in situ $\mathrm{pH}$ profile records the $\mathrm{CO}_{2} / \mathrm{HCO}_{3}^{-} / \mathrm{CO}_{3}^{\overline{3}}$ equilibrium. This chemical equilibrium shifts due to photosynthetic activity of benthic microalgae (Fig. 4). Therefore, measuring should take place under in situ conditions and should avoid sudden changes in irradiance or temperature so that the microalgae maintain their steady state. Coupling of photosynthetic activity to $\mathrm{pH}$ gradients can be achieved by simultaneous measurements or by a very short time lapse requiring electrodes with short response times.

The contribution of adjacent layers to the $\mathrm{pH}$ is maximally $30 \%$ at a bulb-size of a $1 \mathrm{~mm}$ diameter when measuring $0.1 \mathrm{~mm}$ intervals. At this spatial resolution the $\mathrm{pH}$ measured is an average over the $\mathrm{pH}$ gradient existing in this interval. Peak values of $\mathrm{pH}$ tend to be slightly underestimated as both the upper and lower adjacent $0.1 \mathrm{~mm}$ layer will affect the stabilized value. In an increasing or decreasing $\mathrm{pH}$ gradients this error will be much smaller as the effects of the upper and lower adjacent layers will tend to cancel out.

Table 1 summarizes the specific properties of the described $\mathrm{pH}$ mini-electrode compared with 2 types of $\mathrm{pH}$-microelectrodes and 1 type of commercially available $\mathrm{pH}$ mini-electrode. Except for the commercial $\mathrm{pH}$ mini-electrode, all types showed high sensitivity, low drift, and minimal response times of 5 to $15 \mathrm{~s}$. The choice of the electrode type depends strongly on the structure of the sediment and its infauna. Until now, measuring sub-millimeter $\mathrm{pH}$ changes was restricted to fine-grained sediments where microelectrodes could be used at a reduced risk of breaking (Revsbech 1983. Revsbech et al. 1983, 1984, Jørgensen et al. 1983). Meyers et al. (1987) were unable to use pH microelectrodes in their study of microdistribution of interstitial fauna in sandy sediments. The larger-sized and more sturdy $\mathrm{pH}$ mini-electrodes performed very well in sandy sediments without breaking (Fisher \& Matisoff 1981 , this study). We used the same electrode type in river sediments with salinities below $3 \%$ and found values close to Nernstian values up to $\mathrm{pH}=11$. Therefore, this rapidly responding $\mathrm{pH}$ mini-electrode can

Table 1. Comparison of specific properties of $4 \mathrm{pH}$ electrodes

\begin{tabular}{|c|c|c|c|c|}
\hline \multirow[b]{2}{*}{$\begin{array}{l}\text { Electrode } \\
\text { characteristic }\end{array}$} & \multicolumn{2}{|c|}{ Mini-electrodes } & \multicolumn{2}{|c|}{ Microelectrodes } \\
\hline & This study & $\begin{array}{c}\text { Fisher \& Matisoff } \\
\text { (1981) }\end{array}$ & $\begin{array}{c}\text { Carter \& Pucacco } \\
\text { (1978) }\end{array}$ & $\begin{array}{c}\text { Revsbech et al } \\
\text { (1983) }\end{array}$ \\
\hline Tip size & $500-1000 \mu \mathrm{m}$ & $800 \mu \mathrm{m}$ & $3-150 \mu \mathrm{m}$ & $50 \mu \mathrm{m}$ \\
\hline Sensitivity & $95-98 \%$ & $97.5 \%$ & $>97 \%$ & $>95 \%$ \\
\hline Response time & $5-15 s$ & $30-60 s$ & $15-180 \mathrm{~s}$ & $10-60 \mathrm{~s}$ \\
\hline Drift & $<1 \%$ & $-1 \%$ & $<10 \%$ & Unknown \\
\hline Resolution & $\geqslant 100 \mu \mathrm{m}$ & $\geqslant 800 \mu \mathrm{m}$ & $\geqslant 10 \mu \mathrm{m}$ & $\geqslant 100 \mu \mathrm{m}$ \\
\hline
\end{tabular}


make a useful contribution toward the understanding of the biological and chemical processes occurring in sandy sediments.

Acknowledgements. We express our gratitude for the thoughtful comments obtained from $W$ Admiraal, F. Colijn, W. Helder, J. G. Kuenen, H. J. Laanbroek, P. H. Nienhuis and B. Vanheel

\section{LITERATURE CITED}

Butler, R. A., Covington, A. K., Whitfield, M. (1985). The determination of $\mathrm{pH}$ in estuarine waters. II. Practical cansiderations. Oceanologica Acta 8: 433-439

Carter, N. W., Pucacco, L. R. (1978). Measurements of pH by glass microelectrodes. In: Martinez-Maldonaldo, M. (ed.) Methods in pharmacology. Plenum, New York, p. 195-220

Fisher, J. B., Matisoff, G. (1981). High resolution vertical profiles of $\mathrm{pH}$ in recent sediments. Hydrobiologia 79: $277-284$

Jørgensen, B. B., Revsbech, N. P., Cohen, Y (1983). Photosynthesis and structure of benthic microbial mats: microelectrode and SEM studies of four cyanobacterial communities. Limnol. Oceanogr. 28; 1075-1093

Lakshminarayanaiah, N. (1976). Membrane electrodes. Academic Press, New York

Meyers, M. B., Fossing, H., Powell, E. N. (1987). Microdistribution of interstitial meiofauna, oxygen and sulfide gradients, and the tubes of macro-infauna. Mar. Ecol. Prog. Ser. 35: 223-241.
Millero, F. J. (1986). The $\mathrm{pH}$ of estuarine waters. Limnol. Oceanogr. 31: 839-847

Rasmussen, M. B., Henriksen, K., Jensen, A. (1983). Possible causes of temporal fluctuations in primary productions of the microphytobenthos in the Danish Wadden Sea. Mar Biol. 73: 109-114

Revsbech, N. P. (1983). In situ measurement of oxygen profiles by use of oxygen microelectrodes. In: Gnaigner, E., Forstner, H. (eds.) Handbook on polarographic oxygen sensors: aquatic and physiological applications. Springer Heidelberg, p. 265-273

Revsbech, N. P., Jørgensen, B. B. (1983). Photosynthesis of benthic microflora measured with high spatial resolution by the oxygen microprofile method: capabilities and limitations of the method. Limnol. Oceanogr. 28: 749-756

Revsbech, N. P., Jorgensen, B. B., Blackburn, T H., Cohen, Y (1983). Microelectrode studies of the photosynthesis and $\mathrm{O}_{2}, \mathrm{H}_{2} \mathrm{~S}$ and $\mathrm{pH}$ profiles of a microbial mat. Limnol. Oceanogr. 28: 1062-1074

Revsbech, N. P., Ward, D. M. (1984). Microprofiles of dissolved substances and photosynthesis in microbial mats measured with microelectrodes. In: Liss, A. R. (ed.) Microbial mats: stromatolites. A. L. Liss Inc., New York, p. 171-188

Schwabe, K. (1974). pH measurements and their applications. Adv. Anal. Chem. Instrum. 10: 495-586

Thomas, R. C. (1978). Ion-sensitive intracellular microelectrodes: how to make them and use them. Academic Press, New York

Whitfield, M., Butler, R. A., Covington, A. K. (1985). The determination of $\mathrm{pH}$ in estuarine waters. I. Definition of $\mathrm{pH}$ scales and the determination of buffers. Oceanologica Acta 8: $423-432$

This article was submitted to the editor; it was accepted for printing on March 23, 1988 